\title{
Measurement of spatial and temporal fine sediment dynamics in a small river
}

\author{
Y. Schindler Wildhaber ${ }^{1}$, C. Michel ${ }^{2}$, P. Burkhardt-Holm ${ }^{2}$, D. Bänninger ${ }^{1, *}$, and C. Alewell ${ }^{1}$ \\ ${ }^{1}$ Institute for Environmental Geosciences, Basel, Switzerland \\ ${ }^{2}$ Man-Society-Environment MGU, Basel, Switzerland \\ *now at: Environment protection and energy agency, Liestal, Switzerland
}

Correspondence to: Y. Schindler Wildhaber (yael.schindler@ unibas.ch)

Received: 23 November 2011 - Published in Hydrol. Earth Syst. Sci. Discuss.: 20 December 2011

Revised: 23 April 2012 - Accepted: 5 May 2012 - Published: 23 May 2012

\begin{abstract}
Empirical measurements on fine sediment dynamics and fine sediment infiltration and accumulation have been conducted worldwide, but it is difficult to compare the results because the applied methods differ widely. We compared common methods to capture temporal and spatial dynamics of suspended sediment (SS), fine sediment infiltration and accumulation and tested them for their suitability in a small, canalized river of the Swiss Plateau. Measurement suitability was assessed by data comparison, relation to hydrological data and in the context of previously published data. SS concentration and load were assessed by optical backscatter (OBS) sensors and SS samplers. The former exhibit a better temporal resolution, but were associated with calibration problems. Due to the relatively low cost and easy mounting of SS samplers, they can provide a higher spatial distribution in the river's cross section. The latter resulted in a better correlation between sediment infiltration and SS load assessed by SS samplers than SS concentrations measured with OBS sensors. Sediment infiltration baskets and bedload traps capture the temporal and spatial distribution of fine sediment infiltration. Data obtained by both methods were positively correlated with water level and SS. In contrast, accumulation baskets do not assess the temporal behaviour of fine sediment, but the net accumulation over a certain time period. Less fine sediment accumulated in upwelling zones and within areas of higher mean water level due to scouring of fine sediments. Even though SS and sediment infiltration assessed with the bedload traps increased from up- to downstream, less fine sediment accumulated downstream. This is probably also attributable to more scouring downstream.
\end{abstract}

\section{Introduction}

Fine sediment $(<2 \mathrm{~mm})$ load in rivers are generally increasing throughout the world in catchments that are impacted both directly and indirectly by human activities (Owens et al., 2005). Sediment supply in the alpine Rhine basin is estimated to increase between $220 \%$ and $284 \%$ by the year 2100 due to climate and land use change (Asselman et al., 2003). These observed and anticipated changes in fine sediment dynamics in rivers can provide a serious threat to aquatic ecosystems, including phytoplankton, aquatic invertebrates and fish (for a review see Bilotta and Brazier, 2008). Salmonid fish can be affected by suspended sediments (SS) in several ways. While SS can directly impact health and fitness of free swimming fish (Newcombe and Jensen, 1996), fine sediment deposition in the gravel bed can induce siltation of the riverbed resulting in a decrease in hydraulic conductivity (Schälchli, 1995). This affects the oxygen supply to the developing salmonid embryos in the redd negatively, which inhibits the incubation success (Greig et al., 2005). The consequences of climate and land use change on the transport of sediment into rivers, on sediment transport in the river and on clogging processes are poorly known. Studies for the Alps, pre-Alps and the hilly regions of the Swiss Plateau are rare. This includes small rivers, which are habitats for gravel spawning fish (Scheurer et al., 2009).

Several studies have shown a strong correlation between sediment deposition and the occurrence of fine sediment in the water column. Higher fine sediment load in rivers generally lead to increased fine sediment infiltration into the riverbed (Acornley and Sear, 1999; Zimmermann and Lapointe, 2005), while periods of low flow and smaller SS 
concentration and load trigger low sediment infiltration rates with finer grain sizes (Sear, 1993; Soulsby et al., 2001). Consequently, direct measurements of SS concentration and load may be a straight forward method to assess sediment deposition. The estimation of SS concentrations from turbidity measurements with optical backscatter (OBS) sensors depends on the content of fine particulate organic matter as well as grain size distribution of the SS and colour and shape of the grains (Packman et al., 1999). Accordingly, OBS turbidity measurements require calibration at individual test sites.

Deposition of fine sediments is not only controlled by SS concentration, but also by flow hydraulics and inter-gravel flow. These specific hydraulic conditions, influenced by the topography and the permeability of the riverbed, can have a large influence on sediment deposition (Brunke, 1999; Seydell et al., 2009). Seydell et al. (2009) found significantly higher fine sediment infiltration rates in downwelling zones than upwelling zones. Furthermore, sediment infiltration is dependent on flow velocity (Brunke, 1999). Rivers of the hilly regions of the Swiss Plateau and other regions in Europe are generally canalized and laterally stabilized by terraces for land drainage and flood control. These terraces lower the flow velocity and trigger downwelling processes upstream of the terraces, resulting in an increase of fine sediment infiltration (Bucher, 2002). Additionally, terraces may impede desiltation, i.e., processes that increase hydraulic conductivity attributable to higher bed-shear stress (Schälchli, 1995).

Numerous studies have been conducted on fine sediment dynamics and fine sediment infiltration and accumulation in Canada (e.g. Julien and Bergeron, 2006; Levasseur et al., 2006; Zimmermann and Lapointe, 2005), the USA (e.g. Lisle and Lewis, 1992), and the United Kingdom (e.g. Greig et al., 2005; Heywood and Walling, 2007; Sear, 1993; Soulsby et al., 2001). The results of those empirical studies of fine sediment infiltration rates are difficult to generalize mostly due to different measurement methodologies (Sear et al., 2008). Hence, there is a need to compare methodologies as well as data on sediment input and riverbed clogging to achieve a better comparability of results from different studies and to increase knowledge on the interaction between fine sediment dynamics and fine sediment infiltration and accumulation (Scheurer et al., 2009). The aim of this study was to (i) compare results obtained by different methods used to capture temporal and spatial dynamics of suspended sediment and fine sediment infiltration and accumulation, (ii) test their suitability for a river in the Swiss Plateau, (iii) compare the results with hydrological data, and (iv) compare the results with literature data. Because these questions are crucial for gravel spawning salmonid embryos, the study was conducted in artificial redds.

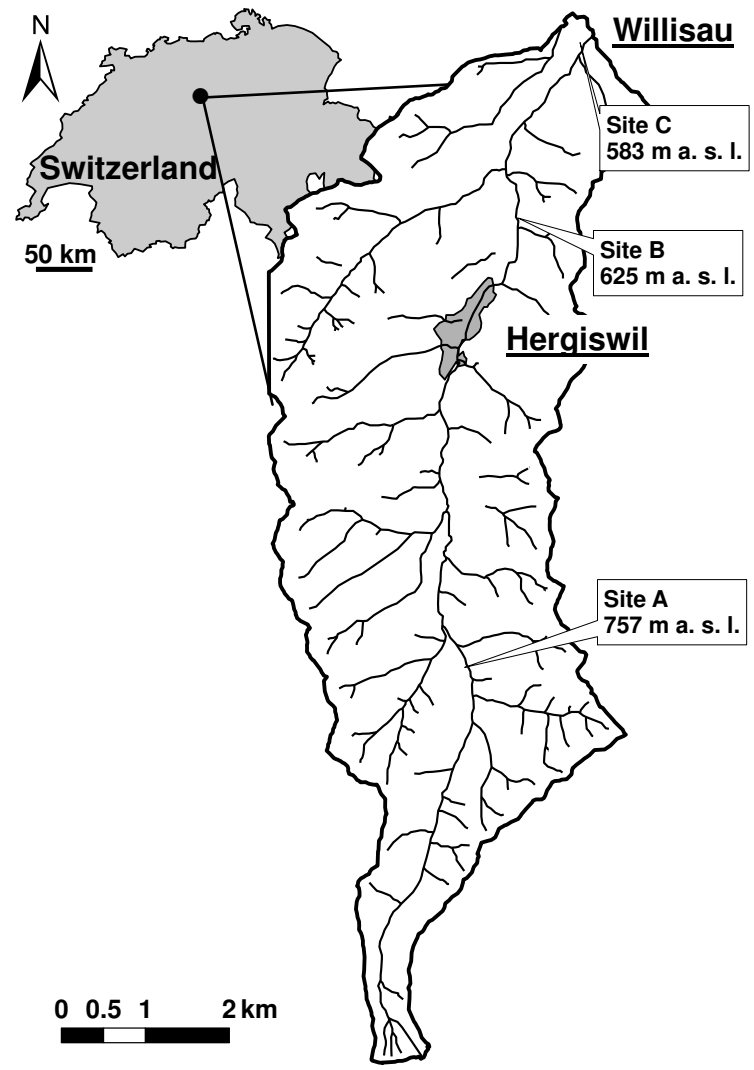

Fig. 1. Watershed of the river Enziwigger with the three field sites A, B and C and the towns Willisau and Hergiswil (Canton of Lucerne, Switzerland).

\section{Materials and methods}

\subsection{Study site and general setup}

The river Enziwigger is a small canalized river located near Willisau (Canton of Lucerne, Switzerland) with a total watershed area of about $31 \mathrm{~km}^{2}$ (Fig. 1). The flow regime of the Enziwigger is not affected by hydro-power and no waste water treatment plant is located above Willisau. Like most rivers in the Swiss Plateau, its morphology is strongly modified: only $5 \%$ of the ecomorphology is close to natural or natural, $21 \%$ is little affected and $74 \%$ is strongly affected or even artificial, including terraces that have been inserted to prevent deep channel erosion and scouring of the bed during flood events (classified with the Swiss modular stepwise procedure for ecomorphology after Hütte and Niederhauser (1998) (EBP-WSB-Agrofutura, 2005)). In spite of these strong modifications its biological condition (classified with the macrozoobenthos module of the Swiss modular stepwise procedure (Stucki, 2010)) is considered good (EBP-WSBAgrofutura, 2005). The only fish species in the Enziwigger is the brown trout, Salmo trutta (EBP-WSB-Agrofutura, 2005). 

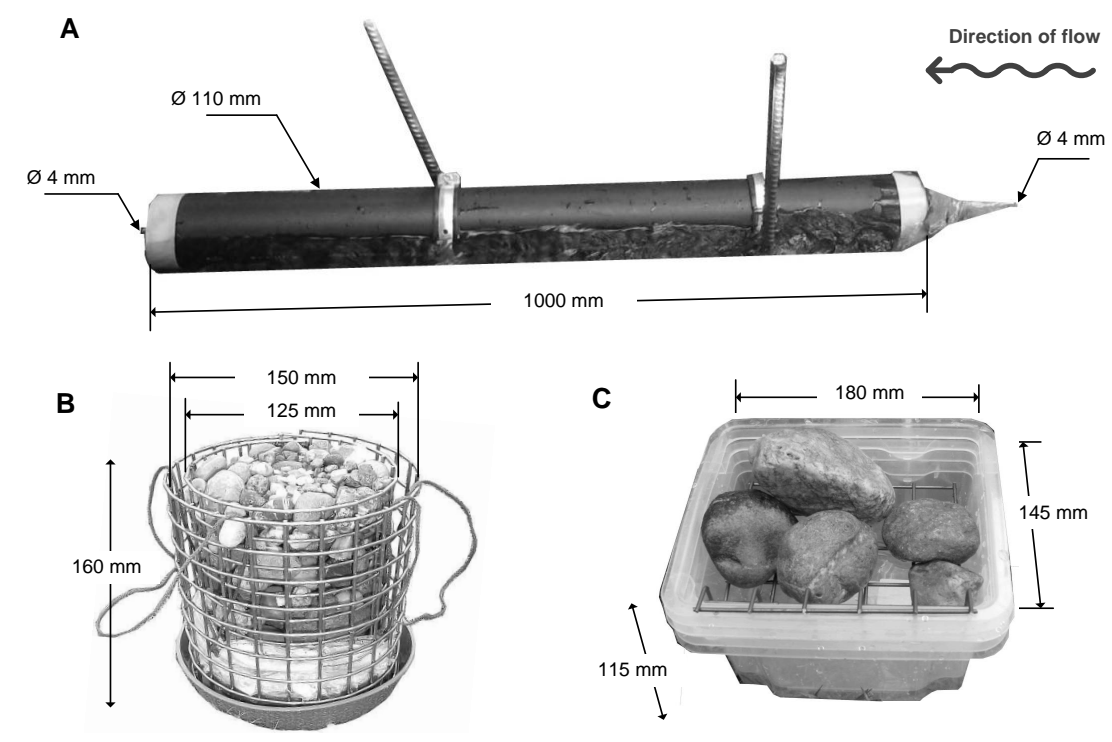

Fig. 2. Devices used to measure fine sediment dynamics in the redds. (A): suspended sediment sampler, (B): sediment infiltration/accumulation basket, $(\mathbf{C})$ : bedload trap.

The bedrock of the watershed consists of Upper Freshwater Molasse. The soil types are mainly (stagnic) Cambisol and Leptosol (classified according to WRB; IUSS, 2006). The mean annual temperature in Willisau is $8.5^{\circ} \mathrm{C}$, with a mean annual rainfall of $1050 \mathrm{~mm}$. Mean annual rainfall on the peak of the mountain Napf, where the river Enziwigger originates, is $1700 \mathrm{~mm}$ per year (1961-2007; data from MeteoSwiss). Discharge was measured in Willisau from November 2007 until November 2008 by the Canton of Lucerne. Mean discharge was $2.1 \mathrm{~m}^{3} \mathrm{~s}^{-1}$, minimum discharge was $1.1 \mathrm{~m}^{3} \mathrm{~s}^{-1}$, and maximum $10.1 \mathrm{~m}^{3} \mathrm{~s}^{-1}$.

Measurements were set up in artificial salmonid redds located at three experimental sites along the river named A, B and C (from up- to downstream; Fig. 1) at altitudes of 757, 625 and $583 \mathrm{~m}$ above sea level (for site characteristics see Table 1). Each site was equipped with six artificial redds in places where natural brown trout redds had been mapped in November 2008. The locations of the redds are mostly consistent over years (Philip Amrein, fish warden of the Canton of Lucerne, personal communication, 2009). Data were assessed during two spawning seasons (Season 1: November 2009 to end of March 2010; Season 2: November 2010 to end of March 2011) in 18 artificial redds per year $\left(n_{\text {tot }}=36\right)$.

\subsection{OBS sensors and time integrated samplers to measure suspended sediment}

Turbidity was measured continuously every $15 \mathrm{~s}$ during both field periods at each site with one optical back scatter (OBS) probe (Campbell Scientific, OBS-3+). The median from 40 measurements was logged every $10 \mathrm{~min}$. The probes were mounted about $5 \mathrm{~cm}$ above the riverbed (about $20 \mathrm{~cm}$ depth during baseflow conditions). To calibrate the nephelometric turbidity unit (NTU) to suspended sediment concentration $\left(\mathrm{SSC}_{\mathrm{NTU}}\right)$ in $\mathrm{mgl}^{-1}$, water samples were taken every seven hours with an automatic water sampler (ISCO 6700, Isco Inc., USA). Because of freezing of the suction hose during the first field season, manual water samples were taken weekly during the second field season. The latter were complemented with samples collected by local habitants during storm events. Water samples were taken to the laboratory to asses the total SSC (see Sect. 2.7).

Time-integrated suspended sediment (SS) samplers following Phillips et al. (2000) were installed behind each redd and emptied at weekly intervals to determine the spatial variation of the SS load (Fig. 2a). The SS samplers were one metre long and consisted of commercially available PE pipes with an outer diameter of $110 \mathrm{~mm}$ and a wall thickness of $4.2 \mathrm{~mm}$. They were sealed with a plugged polyethylene funnel at the inlet and a cap at the outlet. An aluminum tube with an inner diameter of $4 \mathrm{~mm}$ was passed through the funnel and the cap as inlet and outlet. The SS samplers were mounted parallel to the riverbed at two upright steel bars driven into the channel bed, with the inlet tube pointing directly into the direction of the flow. The greater cross-sectional area of the main cylinder compared to that of the inlet tube reduces the flow velocity within the samplers by a factor of 600 relative to that of the ambient flow. This reduction in flow velocity induces sedimentation of the SS particles as the water moves through the cylinder towards the outlet tube (Phillips et al., 2000). The SS samplers collect a statistically representative sample under field conditions (Phillips et al., 2000). 
Table 1. Site characteristics: $D_{50}$ of the riverbed sediment was defined by freeze core samples and with line-number-analyses (Fehr, 1987). Data are given as mean \pm standard deviation.

\begin{tabular}{lrrr}
\hline Site & A & B & C \\
\hline Altitude (m a.s.l.) & 757 & 625 & 583 \\
Watershed area $\left(\mathrm{km}^{2}\right)$ & 5.5 & 22.6 & 28.9 \\
Mean watershed slope $\left({ }^{\circ}\right)^{\mathrm{a}}$ & 26.0 & 20.3 & 19.5 \\
River slope at the site $\left({ }^{\circ}\right)^{\mathrm{b}}$ & 5.0 & 1.5 & 1.4 \\
River slope of riffle between 2 terraces $\left({ }^{\circ}\right)$ & 0.27 & 0.24 & 0.23 \\
$D_{50}$ (freeze core) $(\mathrm{mm})$ & $20 \pm 4$ & $19 \pm 6$ & $16 \pm 1$ \\
$D_{50}$ (line-nr-analysis) $(\mathrm{mm})$ & $25 \pm 8$ & $25 \pm 4$ & $16 \pm 4$ \\
Channel width $(\mathrm{m})$ & $3-3.5$ & $4-4.5$ & $4.5-5$ \\
Water depth above redds $(\mathrm{cm})$ & $10.9 \pm 3.9$ & $23.2 \pm 6.0$ & $20.9 \pm 7.9$ \\
Step length (m) & $11-15$ & $9-12$ & $7-10$ \\
Mean bed shear stress above redds $(\mathrm{Pa})^{\mathrm{c}}$ & 5.0 & 9.5 & 8.2 \\
\hline
\end{tabular}

a Calculation based on the slope value for each pixel from a digital elevation model of the watershed.

$\mathrm{b}$ Based on the slope value from a digital elevation model. ${ }^{\mathrm{c}}$ Calculated by the reach-average bed shear stress

formula: $\tau_{0}=\rho g R S$, where $\tau_{0}$ is bed shear stress, $\rho$ is water density, $g$ is acceleration due to gravity,

$R$ is hydraulic radius at mean water level and $S$ is the slope.

\subsection{Sediment baskets to measure fine sediment infiltration and accumulation}

Fine sediment infiltration and accumulation was determined with sediment baskets (Fig. 2b; cf. Acornley and Sear, 1999; Heywood and Walling, 2007; Greig et al., 2005). They consisted of two baskets made of $20 \times 20 \mathrm{~mm}$ wire mesh with $2.5 \mathrm{~mm}$ wire and a solid bottom. The inner baskets had a diameter of $125 \mathrm{~mm}$ and were $160 \mathrm{~mm}$ deep. They were filled with riverbed sediment $>4 \mathrm{~mm}$ to start with initial conditions without fine sediments. A second basket with a diameter of $150 \mathrm{~mm}$ was dug in the riverbed as a placeholder. A polyethylene bag with two long handles was placed around the inner baskets and stuffed between the two baskets. The bag was pulled over the inner basket during sampling to prevent loss of fine sediment during removal of the inner basket.

Each redd was equipped with two sediment baskets. One of them was emptied at weekly intervals to investigate the weekly fine sediment infiltration rates (= sediment infiltration basket). The baskets' sediment was sieved with a $4 \mathrm{~mm}$ sieve and refilled with the same sediment during each sampling event. Sediment $<4 \mathrm{~mm}$ was taken to the laboratory for grain size analyses. The second set of sediment baskets was emptied only at the end of the spawning season to asses the total net accumulation of fine sediment during the incubation period (= accumulation basket; Sear et al., 2008). During Season $1(2009 / 2010) 10$ of the initial 18 accumulation baskets were washed away at high flow. Two accumulation baskets in each redd were, therefore, installed during Season 2 (2010/2011).

\subsection{Bedload traps to measure sediment transported along the bed}

The volume of the described sediment infiltration baskets is small and most of the space within the trap is taken up by coarse bed material. Thus, these baskets can fill very quickly in situations where sediment loads are high, resulting in an underestimation of the sediment infiltration rate (Bond, 2002). Bedload traps similar to Bond (2002) were designed to overcome this problem. They consisted of two nestable $180 \times 145 \times 115 \mathrm{~mm}$ dug boxes with a $25 \times 25 \mathrm{~mm}$ wire lid, above which coarse bed material was placed to avoid resuspension of the settled material in the trap (Fig. 2c). To empty the box, it was covered by a lid and the inner box was removed. The coarse bed material above the trap caused turbulence; consequently, part of the settled fine sediment might not be material transported as bedload, but also as suspension. We still call the described traps "bedload samplers" to clearly distinct them from the sediment infiltration baskets and to use the same nomenclature as Bond (2002). During the first field season, each redd was equipped with one bedload trap, which was emptied weekly. No bedload traps were installed during the second field season.

\subsection{Hydraulic conditions}

The temporal dynamic of the water level at the three sites was measured every $15 \mathrm{~s}$ during both seasons with pressure transmitter probes (STS, Sensor Technik Sirnach, Switzerland). Average values were logged at $10 \mathrm{~min}$ intervals. The water level above each redd was measured weekly to assess its spatial and temporal variability within a site.

The vertical hydraulic gradient in the redds was measured weekly within mini piezometers designed after Baxter et al. (2003) and installed in the pit and tail of each redd. 
The piezometers had a length of $300 \mathrm{~mm}$ and consisted of a $25 \mathrm{~mm}$ diameter polypropylene (PP) pipe with an inner diameter of $21.4 \mathrm{~mm}$. They were perforated with approximately 30 evenly spaced holes in the lower $160 \mathrm{~mm}$ and plugged at the bottom. The vertical hydraulic gradient is a unitless measure that is positive under upwelling conditions and negative under downwelling condition. It is calculated by the formula

$\mathrm{VHG}=\Delta h / \Delta l$

where VHG is the vertical hydraulic gradient, $\Delta h$ is the difference in head between the water level in the piezometer and the level of the stream surface and $\Delta l$ is the depth from the streambed surface to the first opening in the piezometer sidewall (Baxter et al., 2003).

\subsection{Freeze core samples}

Freeze core samples were taken with a copped and plugged $400 \mathrm{~mm}$ diameter steel pipe. The pipe was pounded in the river sediment to a depth of approximately $350 \mathrm{~mm}$ and filled with liquid nitrogen. Freeze cores with a length of roughly $350 \mathrm{~mm}$ and a diameter of about $150 \mathrm{~mm}$ were removed and divided vertically in $100 \mathrm{~mm}$ wide layers. Sediment from the cores was taken to the laboratory, dried and sieved.

\subsection{Sample analyses}

The grain size distributions of the sediments were determined with the standardized sieve technique using sieves of different mesh sizes. Grains with a diameter $<32 \mu \mathrm{m}$ were measured with a sedigraph (Micrometrics 100, Coulter Electronics, Germany). Grain size fractions were named according to the German soil taxonomy: Sand: $63 \mu \mathrm{m}-2 \mathrm{~mm}$, silt: $2 \mu \mathrm{m}-$ $63 \mu \mathrm{m}$ and clay: $<2 \mu \mathrm{m}$ (Sponagel et al., 2005). Water samples for determination of suspended sediment concentrations were filtered through pre-weighed Whatman-filters with $11 \mu \mathrm{m}$ pore diameter, dried at $40^{\circ} \mathrm{C}$ and weighed. Organic carbon concentration was measured with a $\mathrm{CHN}$-Analyzer (Leco, USA).

\section{Results and discussion}

\subsection{Suspended sediment}

\subsubsection{Turbidity measured by optical backscatter sensors}

The calibration of NTU values to suspended sediment concentration $\left(\mathrm{SSC}_{\mathrm{NTU}}\right)$ was difficult and associated with a high variance (Fig. 3). The calibration curve has an offset to the zero-point, indicating a systematic measurement error. Some general statements, however, were possible: $\mathrm{SSC}_{\mathrm{NTU}}$ varied at all sites between 2 and $10 \mathrm{mgl}^{-1}$ during low flow conditions and increased at high flow ranging from around $150 \mathrm{mg} \mathrm{l}^{-1}$ (site A) to around $300 \mathrm{mg} \mathrm{l}^{-1}$ (site C). Only small

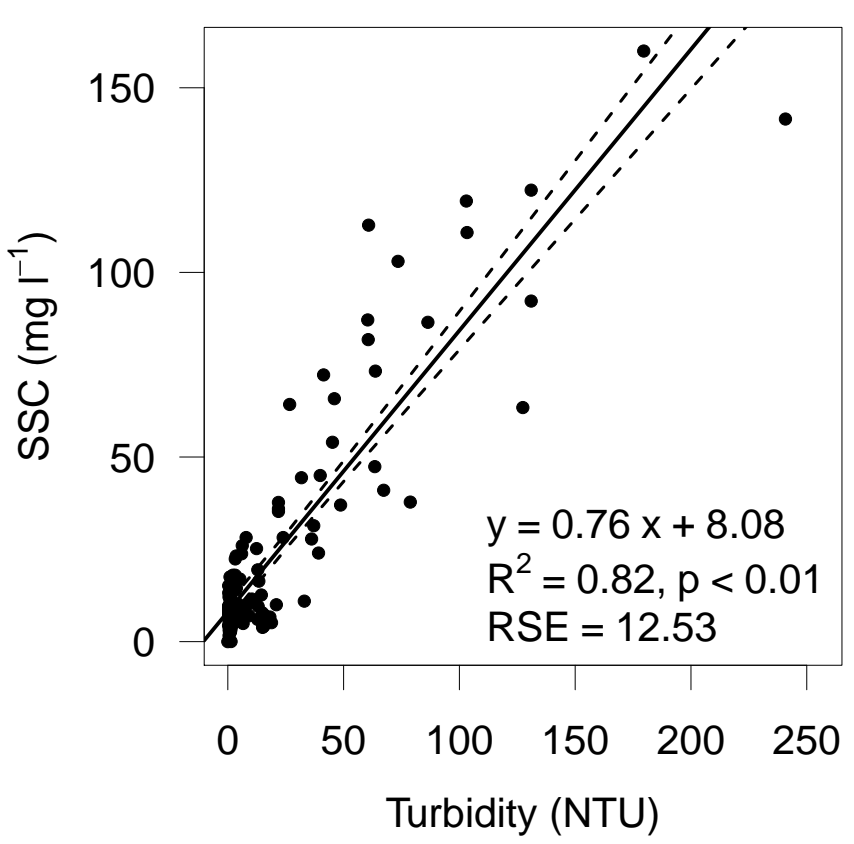

Fig. 3. Correlation between turbidity in NTU and suspended sediment concentration (SSC). Dashed lines are the $95 \%$ confidence intervals; RSE $=$ residual standard error $($ degree of freedom $=154)$

floods occurred during the second field season, resulting in significant smaller mean $\mathrm{SSC}_{\mathrm{NTU}}$ at all sites with an overall mean of $17.0 \mathrm{mg} \mathrm{l}^{-1}$ compared to an overall mean of $42.7 \mathrm{mg}^{-1}$ during the first season (t-test, $p<0.01$; Table 2). $\mathrm{SSC}_{\mathrm{NTU}}$ increased significantly from upstream (site A) to the two downstream sites (B and $\mathrm{C}$ ) during both seasons (ANOVA, $p<0.01$; Table 2). The high mean $\mathrm{SSC}_{\mathrm{NTU}}$ at site $\mathrm{B}$ for the second season might partly be related to measurement artifacts since the OBS sensor at this site was often shielded by leaves. Even though obvious outliers were excluded from the dataset, many high value data points remained in the dataset. These values could not be excluded with certainty, but might still be influenced by measurement artifacts.

The high temporal resolution in $\mathrm{SSC}_{\mathrm{NTU}}$ data is an advantage of the OBS sensors. $\mathrm{SSC}_{\mathrm{NTU}}$ increased rapidly with increasing water level at all sites and there is evidence of sediment exhaustion during the falling limb of flood events (Fig. 4). The observed simultaneous peaks in discharge and $\mathrm{SSC}_{\mathrm{NTU}}$ correspond to the remobilization and transport of in-channel sediments (e.g. Duvert et al., 2010). Although OBS sensors are widely used for turbidity measurements, their handling is an often underestimated problem (for a review see Downing, 2006). The most frequent problems with OBS sensors are their signal dependence on grain size distribution and on sediment composition (shape of particles) as well as algal growth on the sensor windows (Downing, 2006; Minella et al., 2008; Packman et al., 1999). An infinite number of combinations of sediment characteristics, 
Table 2. Mean and standard deviation of suspended sediment concentration ( $\mathrm{SSC}_{\mathrm{NTU}}$ ) measured with the OBS sensors and suspended sediment (SS) load caught by suspended sediment samplers at the three sites during the two field seasons.

\begin{tabular}{|c|c|c|c|c|}
\hline \multirow[b]{2}{*}{ Site } & \multicolumn{2}{|c|}{ Field season $1(2009 / 2010)$} & \multicolumn{2}{|c|}{ Field season $2(2010 / 2011)$} \\
\hline & $\mathrm{SSC}_{\mathrm{NTU}}\left(\mathrm{mg} \mathrm{l}^{-1}\right)$ & SS $\left(\mathrm{g}_{\text {week }}{ }^{-1}\right.$ ) & $\mathrm{SSC}_{\mathrm{NTU}}\left(\mathrm{mg} \mathrm{1}^{-1}\right)$ & $\mathrm{SS}\left(\mathrm{g}\right.$ week $\left.^{-1}\right)$ \\
\hline $\mathrm{A}$ & $28.0 \pm 37.8^{* *}$ & $14.4 \pm 3.5^{*}$ & $12.9 \pm 7.6^{* *}$ & $7.0 \pm 1.7 * *$ \\
\hline B & $49.1 \pm 56.5$ & $16.8 \pm 3.3$ & $21.4 \pm 12.8^{*}$ & $11.5 \pm 0.4^{*}$ \\
\hline $\mathrm{C}$ & $54.9 \pm 62.8^{*}$ & $20.3 \pm 2.5^{* *}$ & $16.2 \pm 23.3$ & $11.2 \pm 0.5$ \\
\hline mean & $42.7 \pm 53.3$ & $17.2 \pm 3.9$ & $17.0 \pm 16.5$ & $9.9 \pm 2.3$ \\
\hline
\end{tabular}

Differences between seasons are highly significant for all sites and both measurement devices (t-test, $p<0.01$ ).

* Differs significantly from the two other sites (ANOVA, $p<0.05$ ). ** Differs highly significantly from the two other sites (ANOVA, $p<0.01$ ).

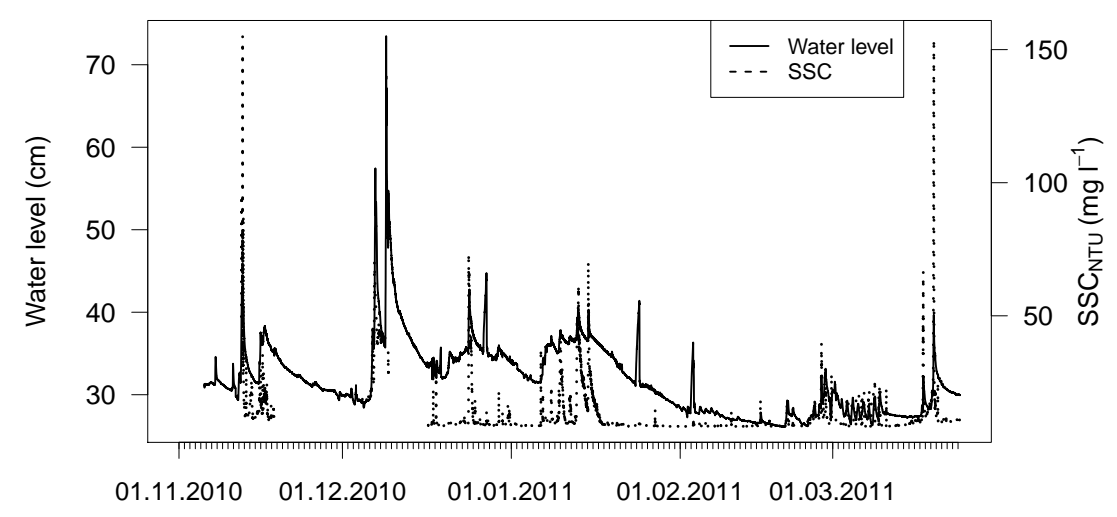

Fig. 4. Example of the temporal variation of the suspended sediment concentration (SSC) and water level (Site A, Season 1).

including size, shape, mineral compositions and surface texture, is possible. Each combination produces a unique signal and each metre has a unique emitter-detector geometry that samples the signal in a particular way (Downing, 2006). NTU is consequently an arbitrary unit, incomparable to NTU measured at other times and places or with different turbidity metres (Downing, 2006). A calibration of NTU to SSC $_{\mathrm{NTU}}$ in $\mathrm{mg}^{-1}$ is necessary for the comparison to other studies. Measurement uncertainty is, however, introduced into the $\mathrm{SSC}_{\mathrm{NTU}}$ data when converting NTU to $\mathrm{SSC}_{\mathrm{NTU}}$ (Downing, 2006; Navratil et al., 2011).

Several problems with the OBS sensors were observed during the two field seasons. Drifting leaves were caught by the sensors in the fall months, resulting in abnormally high NTU values. This was particularly the case at site B during Season 2. More frequent checks at the field site, similar to the SS samplers (see Sect. 3.1.2), could partly counterbalance this shortcoming. Moreover, freezing of the suction hose of the ISCO samplers during the winter interrupted sediment concentration sampling. Regular sediment concentration samples are, however, necessary for a good calibration. Finally, the $D_{50}$ of the SS (50th percentile grain size diameter; data assessed by SS samplers, see Sect. 3.1.2) fluctuated strongly during the field season with a minimum of $6.7 \mu \mathrm{m}$ at low flow with low $\mathrm{SSC}_{\mathrm{NTU}}$ and a maximum of $110.5 \mu \mathrm{m}$ at high flow associated with high $\mathrm{SSC}_{\mathrm{NTU}}$ (Fig. 5). The large effect of the change in grain size distribution on the OBS signal has been documented in numerous studies (for a review see Downing, 2006). Organic carbon concentrations of the suspended sediment were also highly variable with minimum values around $1.5 \%$ at high flow and maximum values around $10.5 \%$ at low flow. This change in organic carbon concentrations has again an influence on the conversion of NTU to SSC $_{\text {NTU }}$ values (Downing, 2006).

\subsubsection{Suspended sediment samplers}

Results from the SS samplers paralleled the observations with the OBS sensors, showing significant higher SS loads during the first season than the second season (t-test, $p<0.01)$ and a SS increase from upstream to downstream (ANOVA, $p<0.01$; Table 2). The SS loads captured during one week by the six SS samplers per site varied highly with coefficients of variation between 12 and $100 \%$. This might represent the well known variation in suspended sediment concentration through the cross-section of rivers (Horowitz et al., 1990; Spreafico et al., 2005). The $D_{50}$ of the SS varied highly across the channel and with time, again representing the variation of SS within a river both with low and high mean SS concentrations in the water column (Fig. 5). 


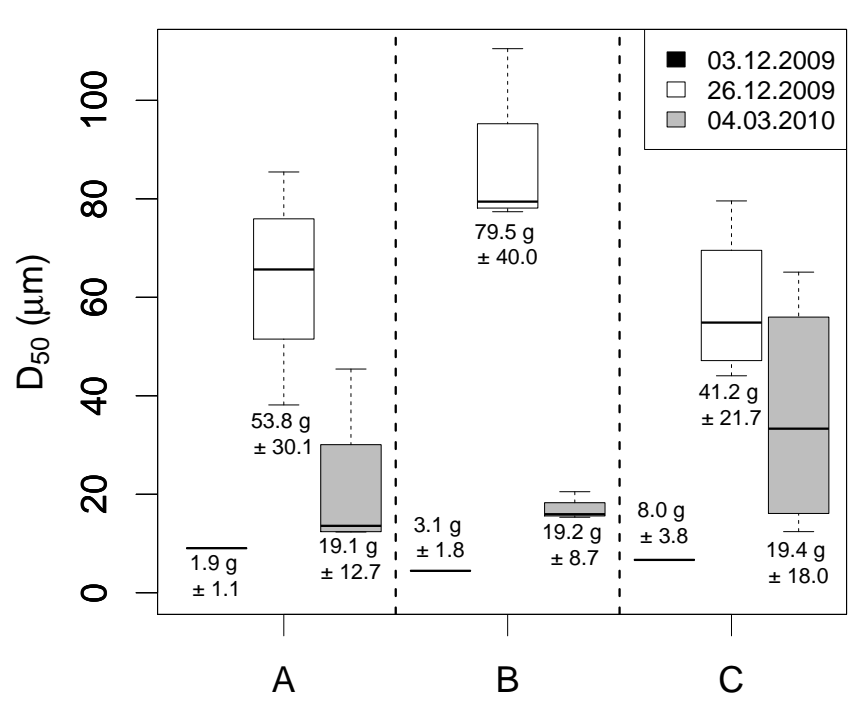

Fig. 5. Weekly $D_{50}$ of the suspended sediment (SS) caught by the SS samplers $(n=6 /$ site $)$ during three weeks at the three sites A, B and C. Mean total amount of SS load \pm standard deviation is given below/above the boxes. The 6 samples of 3 December 2009 had to be merged for grain size analysis because of the small quantity of SS.

The described differences could also partly be attributable to instrumental biases.

The deposited sediments can be retained for further analyses of their composition, which is a major advantage of the SS samplers. In addition, the SS samplers can be installed in a relatively dense sampling network because they are inexpensive and easily fabricated. An installation at specific test sites, for example behind individual artificial redds, is possible. Thus, they can provide information about cross-sectional differences of SS loads and about the SS load at a specific test locations. Problems of this method include clogging of the inlet with leaves and the difficulty of placing the samplers horizontally with the inlet tube directly pointing into the flow direction. Consequently, distinguishing instrumental and sampling errors from spatial and temporal heterogeneity can be difficult. It is, therefore, suggested to closely monitor the samplers to ensure their proper performance, especially during fall when a large number of leaves drift in the river.

\subsection{Sediment infiltration}

A strong temporal variation of fine sediment infiltration with values ranging between $0.01 \mathrm{~kg} \mathrm{~m}^{-2} \mathrm{~d}^{-1}$ during low flow conditions and $10.36 \mathrm{~kg} \mathrm{~m}^{-2} \mathrm{~d}^{-1}$ during peak discharge was found (Table 3). Our results confirm the conclusions of previous field studies showing maximum fine sediment infiltration during peak discharge when sediment transport is high (Soulsby et al., 2001; Zimmermann and Lapointe, 2005; Acornley and Sear, 1999; Greig et al., 2005). At all sites, an exponential increase in sediment infiltration with increas- ing water level was found. Sediment infiltration rates below a certain water level threshold (site A: about $15 \mathrm{~cm}$, site B and C: about $25 \mathrm{~cm}$ ) were very small (Fig. 6). At site B and $\mathrm{C}$, sediment infiltration reached a maximum at a water level around $45 \mathrm{~cm}$. This indicates a saturation or equilibrium of input and scouring at higher water level. This equilibrium was never reached at site A, most likely due to an overall lower water level and, therefore, less scouring (Table 1, Fig. 6).

The sediment infiltration baskets were not filled with homogeneous gravel, but with riverbed gravel collected during redd construction; consequently, the $D_{50}$ $(27.1 \pm 2.1 \mathrm{~mm}$; note here and in the following all values are given as mean $\pm \mathrm{sd}$ ) as well as the sorting coefficient $\left(\mathrm{SO}=\left(D_{75} / D_{25}\right)^{0.5} ; 1.6 \pm 0.1\right)$ among the cleaned sediment baskets differed. Spearman rank correlation tests showed, however, that these differences had no influence on the amount of fine sediment infiltration ( $p=0.5$ and 0.2 respectively).

Sediment infiltration rates during the first season were significantly higher at all sites with a mean of $1.54 \pm 0.24 \mathrm{~kg} \mathrm{~m}^{2} \mathrm{day}^{-1}$ compared to the second season with a mean of $0.74 \pm 0.21 \mathrm{~kg} \mathrm{~m}^{2}$ day $^{-1}$ (t-test, $p<0.01$ ). This is attributable to numerous high flows during the first field season. No significant differences of infiltration rates between the three sites were found (ANOVA, $p<0.3-0.8$ ). The variation of sediment infiltration rates among infiltration baskets at each site was very high with coefficients of variation up to $100 \%$ (Table 4). The most likely explanation for these differences is the cross-channel variation due to the differences in flow velocity caused by bank roughness effects (Acornley and Sear, 1999).

Overall, the observed sediment infiltration rates are relatively high compared to other sediment infiltration studies conducted with sediment baskets (Table 3). These high sediment infiltration rates can partly be explained by the high input of fine sediment from the molasse bedrock in the catchment. Furthermore, the sampling was conducted at a higher frequency than in the other studies (Table 3). The efficiency of newly cleaned gravel in trapping fine sediments is at its maximum with initial conditions and decreases with time (Heywood and Walling, 2007). Hence, weekly sampled sediment baskets will yield higher daily means compared to monthly sampled baskets. Additionally, part of the deposited sediments might be washed out again. The difference between unequal sampling intervals can also be seen in the large discrepancy between the sediment infiltration rates calculated from the weekly obtained sediment infiltration data and those calculated from the accumulation baskets, which were only sampled at the end of the seasons after four months (Table 3). As such, quantitative comparisons of sediment infiltration rates from studies with different sampling intervals have to be done with caution.

Grain size analyses showed an increase of silt and clay with increasing fine sediment infiltration in absolute values 
Table 3. Range or mean \pm standard deviation of infiltration rate (IR) of sediment $<2 \mathrm{~mm}$ in permeable sediment baskets.

\begin{tabular}{llrl}
\hline Reference & Study site & IR $\left(\mathrm{kg} \mathrm{m}^{-2} \mathrm{~d}^{-1}\right)$ & Sampling interval \\
\hline This study & River Enziwigger, Lucerne, Switzerland & $0.01-10.36$ & weekly \\
This study & River Enziwigger, Lucerne, Switzerland & $0.21-0.70$ & 4 month \\
Acornley and Sear (1999) & River Test, Hampshire, UK & $0.02-1.00$ & monthly \\
Acornley and Sear (1999) & Wallop Brook, UK & $0.04-0.40$ & monthly \\
Sear (1993) & North Tyne, Northumberland, UK & $0.005-1.60$ & monthly \\
Seydell et al. (2009) & River Lahn, near Marburg, Germany & $0.16 \pm 0.07$ & two weeks interval \\
Zimmermann and Lapointe (2005) & Cascapédia River, Québec, Canada & $0.006-6.80$ & after suspension event \\
\hline
\end{tabular}

Table 4. Mean and range of daily sediment $<2 \mathrm{~mm}$ infiltration rate (IR) during the two seasons at the three sites and of the coefficient of variation $(\mathrm{CV})$ of the weekly values within the six samplers per site.

\begin{tabular}{lrrrrr}
\hline & \multicolumn{2}{c}{ Field season 1 $(2009 / 2010)$} & & \multicolumn{2}{c}{ Field season 2 $(2010 / 2011)$} \\
\cline { 2 - 3 } \cline { 5 - 6 } Site & IR $\left(\mathrm{kg} \mathrm{m}^{2} \mathrm{day}^{-1}\right)$ & $\mathrm{CV}(\%)$ & & $\mathrm{IR}\left(\mathrm{kg} \mathrm{m}^{2} \mathrm{day}^{-1}\right)$ & $\mathrm{CV}(\%)$ \\
\hline $\mathrm{A}$ & $1.67(0.02-10.36)$ & $32.9(7.6-58.4)$ & & $0.68(0.02-7.57)$ & $31.1(10.5-67.3)$ \\
$\mathrm{B}$ & $1.29(0.01-8.22)$ & $40.6(17.2-75.1)$ & & $0.62(0.03-5.31)$ & $27.5(14.7-50.0)$ \\
$\mathrm{C}$ & $1.55(0.06-7.46)$ & $38.3(0-86.4)$ & & $0.66(0.05-7.38)$ & $48.7(15.5-106.1)$ \\
\hline
\end{tabular}

(Fig. 7, left), but a decrease in relative values (i.e., fraction of silt and clay of the total fine sediment deposition; Fig. 7, right). During periods with low sediment infiltration rates, up to $94 \%$ of the sediment consisted of sediment $<0.25 \mathrm{~mm}$; thus, sediments of a size most likely to be transported in suspension. This agrees with Acornley and Sear (1999) and Sear (1993). They found mainly sediment infiltration composed of sediments transported in suspension $(<0.25 \mathrm{~mm})$ during low flow and a greater proportion of sediments with a diameter between 0.25 and $4 \mathrm{~mm}$ during high flow. This fraction is large enough to be in intermittent contact with the bed, yet small enough to pass through small interstices of the weekly cleaned sediment infiltration baskets (Lisle, 1989).

Sediment infiltration baskets do not represent natural conditions. Sediments $<4 \mathrm{~mm}$ is removed in a regular interval, causing an overestimation of the real capacity of sediment infiltration occurring in the undisturbed riverbed. The suitability of the infiltration baskets strongly depends on the purpose of the research question. They are a quasi standardized method to obtain spatial and temporal differences of fine sediment infiltration or to assess the time needed for siltation of a freshly cut redd. To assess sediment infiltration rates close to natural conditions, Greig et al. (2005) assessed the temporal sediment accumulation by installing multiple small, porous infiltration pots. At each time step ( 2 weeks), two small pots were randomly removed. This allowed them to conduct seven measurements during the spawning period. Problems with this method are the possible spatial variability among the pots and the loss of pots at high flow (see Sect. 3.3). Another measurement strategy could consist of measuring sediment infil- tration from week to week without removing the fine sediment trapped in the baskets, but this also does not represent true natural conditions, since the sediment structure would get disturbed while measuring the infiltrated sediment.

\subsection{Sediment accumulation}

The highest values for fine sediment accumulation over the two seasons were observed at site $\mathrm{A}$, the most upstream site (ANOVA, $p<0.05$ ). On average, $20.1 \%$ of the sediment basket consisted of particles $<2 \mathrm{~mm}$ at site A, $18.7 \%$ at site $\mathrm{B}$ and $13.9 \%$ at site $\mathrm{C}$ (Table 5). The decrease in fine sediment accumulation downstream could be related to higher scouring of fine sediment down the stream due to the higher water level. Sediment accumulation at site B and C did not differ significantly between the two seasons (t-test, $p=0.3$ and 0.5 respectively), despite the significant higher fine sediment infiltration during the first field season at all sites. Only at site A, significantly higher fine sediment accumulation rates were obtained during the first season $(\mathrm{t}-$ test, $p<0.01$, Table 5). Consequently, downstream scouring of fine sediment seems to have a greater effect on sediment accumulation than SS load and sediment infiltration on sediment accumulation.

The sediment accumulation baskets were not filled with standardized gravel but with riverbed gravel to represent natural conditions. These differences in $D_{50}$ as well as in sorting coefficient of the accumulation baskets had no influence on the amount of sediment accumulation (Spearman rank correlation, $p=0.5$ ). 


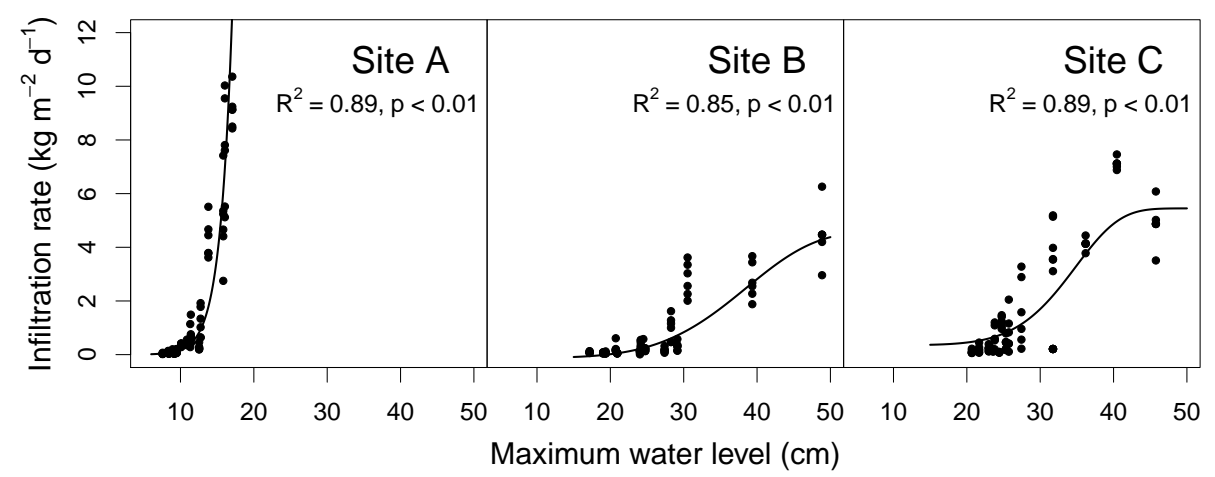

Fig. 6. Sediment infiltration rate in relation to the highest mean daily water level above the redds during the measurement week. The relationship at site $\mathrm{B}$ and $\mathrm{C}$ is described by a Weibull growth function.

A

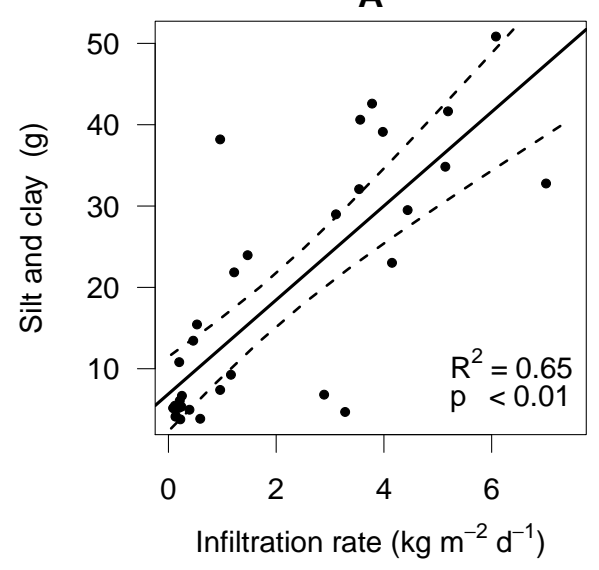

B

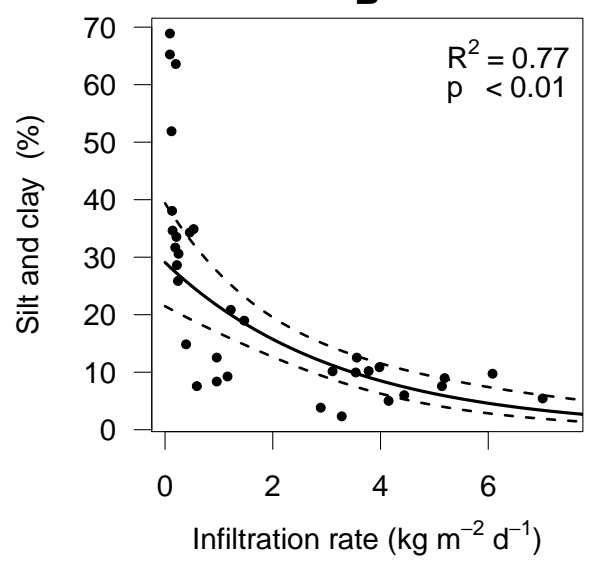

Fig. 7. Weekly silt and clay infiltration at site $\mathrm{C}$ in absolute values (A) and relative values (i.e., fraction of silt and clay of the total fine sediment deposition; (B)) in relation to the daily infiltration rate of sediment $<2 \mathrm{~mm}$. Dashed lines are the $95 \%$ confidence intervals.

Comparisons with other studies revealed similar rates of sediment accumulation to those reported in this study (Table 6). $90 \pm 2.6 \%$ of the accumulated fine sediment was sand and $67 \pm 5.6 \%$ had a diameter $>0.25 \mathrm{~mm}$. Thus, the size most likely carried in suspension $(<0.25 \mathrm{~mm})$ accounted for only $33 \%$ of the sediment accumulated in the sediment basket. This is in the same range as found by Lisle (1989). During high flow the main component of the infiltrated sediment is in the bedload fraction (see Sect. 3.2). This fraction is deposited and accumulated at all depths down to the bottom of the basket as long as size distributions of transported sediment and the riverbed particles do not overlap (Lisle, 1989).

The fine sediment fraction $(<2 \mathrm{~mm})$ in the accumulation baskets was greater than in the riverbed sediment obtained by freeze core samples (Table 5). Because of the high variation among the accumulation baskets and among the freeze core samples, the differences were only significant at site A (t-test, $p<0.01$ ). According to Zimmermann et al. (2005), these differences could reflect the influence of the effective size of the pore spaces available in the substrate on sedi- ment infiltration. The overestimation of fine sediment in the baskets in this study could also be due to the small gap of about $4 \mathrm{~mm}$ between the inner and the outer sediment basket, in which the fine sediment (mainly in the bedload fraction) was able to infiltrate. This gap accounts for about $13 \%$ of the volume of the inner baskets and was entirely filled with fine sediment at the end of the spawning season. The differences could also reflect an overestimation of the coarse fraction by freeze cores since individual pieces of coarse gravel and cobbles protruding out of the freeze cores can result in a smaller percentage of fine sediment of the sample (Young et al., 1991; Zimmermann et al., 2005).

Comparisons with the freeze core samples showed significantly higher silt and clay fractions of the total fine sediment in the accumulation baskets with 7.8 to $10.5 \%$ compared to 4.8 to $5.1 \%$ in the freeze core samples (t-test, $p<0.05$; Table 5). This high fraction in the accumulation baskets is probably attributable to silt and clay particles which would have infiltrated to deeper layers in a natural environment. At the beginning of the measurement campaign, the sediment in 
Table 5. Mean values \pm standard deviation of the fraction of fine sediment $(<2 \mathrm{~mm}$ ) in the accumulation baskets and the fraction of sediment $<63 \mu \mathrm{m}$ of the accumulated fine sediment during the two spawning seasons S1 (2009/2010) and S2 (2010/2911) and in freeze cores (FC) taken in winter 2008/2009 at the three sites.

\begin{tabular}{|c|c|c|c|c|c|c|c|c|}
\hline Site & $\begin{array}{r}\%<2 \mathrm{~mm} \\
\mathrm{~S} 1\end{array}$ & $\begin{array}{r}\%<2 \mathrm{~mm} \\
\mathrm{~S} 2\end{array}$ & $\begin{array}{r}\%<2 \mathrm{~mm} \\
\text { mean }\end{array}$ & $\begin{array}{r}\%<2 \mathrm{~mm} \\
\text { in FC }\end{array}$ & $\begin{array}{r}\%<63 \mu \mathrm{m} \\
\mathrm{S} 1\end{array}$ & $\begin{array}{r}\%<63 \mu \mathrm{m} \\
\mathrm{S} 2\end{array}$ & $\begin{array}{r}\%<63 \mu \mathrm{m} \\
\text { mean }\end{array}$ & $\begin{array}{r}\%<63 \mu \mathrm{m} \\
\text { in FC }\end{array}$ \\
\hline A & $\begin{array}{r}25.5 \pm 1.4^{* *} \\
(n=4)\end{array}$ & $\begin{array}{r}18.0 \pm 3.3 \\
(n=10)\end{array}$ & $\begin{array}{r}20.1 \pm 4.5^{*} \\
\quad(n=14)\end{array}$ & $\begin{array}{r}13.6 \pm 4.1^{++} \\
(n=6)\end{array}$ & $\begin{array}{r}8.2 \pm 1.3 \\
(n=4)\end{array}$ & $\begin{array}{r}11.3 \pm 2.1 * * \\
(n=10)\end{array}$ & $\begin{array}{r}10.4 \pm 2.4 \\
(n=14)\end{array}$ & $\begin{array}{r}5.1 \pm 1.7^{++} \\
(n=6)\end{array}$ \\
\hline B & $\begin{array}{r}16.0 \pm 4.3 \\
(n=2)\end{array}$ & $\begin{array}{r}20.1 \pm 4.4 \\
(n=4)\end{array}$ & $\begin{array}{r}18.7 \pm 4.5 \\
(n=6)\end{array}$ & $\begin{array}{r}13.3 \pm 4.5 \\
(n=6)\end{array}$ & $\begin{array}{r}9.3 \pm 2.4 \\
(n=2)\end{array}$ & $\begin{array}{r}7.0 \pm 1.0 * * \\
(n=4)\end{array}$ & $\begin{array}{r}7.8 \pm 1.8 \\
(n=6)\end{array}$ & $\begin{array}{r}4.8 \pm 1.1^{+} \\
(n=6)\end{array}$ \\
\hline $\mathrm{C}$ & $\begin{array}{r}15.4 \pm 3.3 \\
(n=2)\end{array}$ & $\begin{array}{r}13.1 \pm 2.6 \\
(n=4)\end{array}$ & $\begin{array}{r}13.9 \pm 2.8^{*} \\
(n=6)\end{array}$ & $\begin{array}{r}12.5 \pm 4.1 \\
(n=6)\end{array}$ & $\begin{array}{r}13.8 \pm 4.1 * \\
(n=2)\end{array}$ & $\begin{array}{r}8.9 \pm 0.6 \\
(n=4)\end{array}$ & $\begin{array}{r}10.5 \pm 3.1 \\
(n=6)\end{array}$ & $\begin{array}{r}5.0 \pm 2.5^{+} \\
(n=6)\end{array}$ \\
\hline
\end{tabular}

$*$ Differs significantly from the two other sites (ANOVA, $p<0.05$ ). ** Differs highly significantly from the two other sites (ANOVA, $p<0.01$ ). ${ }^{+}$Differs significantly from the mean fraction of the accumulation baskets (t-test, $p<0.05)$. ${ }^{++}$Differs highly significantly from the mean fraction of the accumulation baskets (t-test, $p<0.01)$.

Table 6. Fine sediment $(<2 \mathrm{~mm})$ and silt and clay $(<63 \mu \mathrm{m})$ accumulation in the accumulation baskets as $\%$ of the whole baskets and the silt and clay fraction of the sediment $<2 \mathrm{~mm}$. Range (mean) or mean \pm standard deviation.

\begin{tabular}{|c|c|c|c|c|}
\hline Reference & Study site & $<2 \mathrm{~mm}(\%)$ & $<63 \mu \mathrm{m}(\%)$ & $<63 \mu \mathrm{m}$ of $<2 \mathrm{~mm}(\%)$ \\
\hline This study & River Enziwigger, Lucerne & $9.6-26.7(18.3)$ & $0.9-2.4(1.7)$ & $6.1-16.7(9.8)$ \\
\hline Greig et al. (2005) & $\begin{array}{l}\text { River Test and Blackwater, } \\
\text { Hampshire }\end{array}$ & $10.0,12.2$ & & \\
\hline Greig et al. (2005) & River Ithon and Aran, Wales & $28.9,15.7$ & & \\
\hline $\begin{array}{l}\text { Heywood and } \\
\text { Walling (2007) }\end{array}$ & Avon catchment, Hampshire & $1.3-17.2$ & & $31 \pm 14$ \\
\hline $\begin{array}{l}\text { Levasseur et } \\
\text { al. }(2006)\end{array}$ & Sainte Margerite River, Quebec & $0.4-27(13.2)$ & $0.04-0.72(0.16)$ & \\
\hline Lisle (1989) & $\begin{array}{l}\text { Coast Range of northern } \\
\text { California }\end{array}$ & & & $4.8-5.9$ \\
\hline $\begin{array}{l}\text { Julien and } \\
\text { Bergeron (2006) }\end{array}$ & Sainte Margerite River, Quebec & $3.3-29.2 *$ & $0.03 \pm 0.02-0.41 \pm 0.2$ & \\
\hline $\begin{array}{l}\text { Zimmermann and } \\
\text { Lapointe (2005) }\end{array}$ & $\begin{array}{l}\text { Cascapédia River watershed, } \\
\text { upper reaches; Québec }\end{array}$ & $3.5-10$ & & $4-9$ \\
\hline
\end{tabular}

the sediment baskets is comparable to a freshly cut redd. This cleaned gravel is vulnerable to deep infiltration by fines before a seal is formed during entrainment of the armor layer (Lisle, 1989). Sediments can only infiltrate to the bottom of the baskets. Freeze core data support this assumption indicating a significant higher silt and clay fraction at a depth of $10-20 \mathrm{~cm}$ and $20-30 \mathrm{~cm}$ with silt and clay content of $6.0 \pm 2.0 \%$ and $6.3 \pm 2.5 \%$, respectively, compared to the upper layer $(0-10 \mathrm{~cm})$ with a silt and clay content of $3.6 \pm 2.4 \%$ (ANOVA, $p<0.01$ ). The fraction of particles $<63 \mu \mathrm{m}$ of the accumulated sediment within a site and between the two seasons varied greatly (Table 5). Therefore, no general conclusions concerning the differences between the three sites and the two seasons can be drawn. The hydraulic differences within a site and the forming of a surface seal of sand (Lisle, 1989) influences the deposition and accumulation of silt and clay particles probably to a larger extent than their abundance in the water column. Silt and clay fractions assessed in other studies were also highly variable, making a comparison difficult (Table 6).

\subsection{Fine sediment transported along the bed}

Mean sediment caught by the bedload samplers increased along the river from $1.93 \mathrm{~kg} \mathrm{~m}^{2} \mathrm{~d}^{-1}$ at site $\mathrm{A}$ to $2.24 \mathrm{~kg} \mathrm{~m}^{2} \mathrm{~d}^{-1}$ at site $\mathrm{C}$ (Table 7). This pattern parallels the data from the SS samplers and OBS sensors and could be related to an increasing shear stress attributable to higher water levels down the stream or/and to a higher input of fine sediments from the arable corn fields in the lower part of the catchment. 
Table 7. Mean and range of daily bedload (BL) $<2 \mathrm{~mm}$, of the percentage of $\mathrm{BL}<2 \mathrm{~mm}$ of the total BL and of the coefficient of variation $(\mathrm{CV})$ of the weekly values within the six samplers at the three sites.

\begin{tabular}{lrrrr}
\hline Site & $\mathrm{BL}<2 \mathrm{~mm}_{\left(\mathrm{kg} \mathrm{m}^{2} \mathrm{~d}^{-1}\right)}$ & $\mathrm{CV}(\%)$ & $\%<2 \mathrm{~mm}$ of BL & $\mathrm{CV} \%<2 \mathrm{~mm}$ of BL $(\%)$ \\
\hline $\mathrm{A}$ & $1.93(0.02-14.26)$ & $72.0(10.7-193.4)$ & $73.8(32.2-98.3)^{* *}$ & $45.0(0-86.6)$ \\
$\mathrm{B}$ & $2.01(0.01-10.80)$ & $79.8(0-183.2)$ & $30.3(4.0-60.6)^{*}$ & $64.2(24.3-96.3)$ \\
$\mathrm{C}$ & $2.24(0.02-8.5)$ & $61.9(0-178.2)$ & $58.7(23.7-92.5)$ & $27.5(0-62.8)$ \\
\hline
\end{tabular}

$*$ Differs significantly from the two other sites (ANOVA, $p<0.05$ ). ** Differs highly significantly from the two other sites (ANOVA, $p<0.01)$.

At all sites, bedload rates were very small until a certain water level (data not shown). Above this level, bedload increased exponentially with increasing water level. This matches the pattern we found with the sediment infiltration baskets (Fig. 6).

The percentage of fines in the total captured bedload was highest at site A (ANOVA, $p<0.01$ ). This is probably also attributable to the low water level compared to the other two sites and the relatively small slope due to the frequent artificial terraces, resulting in lower shear stress (Table 1). The fraction of the bedload smaller than $2 \mathrm{~mm}$ decreased with higher water level and total bedload (Spearman rank correlation, $p<0.01$; Table 8).

Bedload rates and the percentage of fine sediment of the total bedload caught by the six bedload samplers varied highly per site (Table 7). This variations can be partly accounted for by cross-channel differences also observed in the SS load, sediment infiltration and accumulation data. The higher coefficients of variation of the bedload data compared to the other methods is likely explained by (i) the variation in precision in placing the traps flush with the sediment surface. If the border of the trap is not flush with the bed, fine sediment transported along the bed was not trapped and (ii) the turbulence caused by the coarse bed material above the trap, which differs between traps and triggers different trapping efficiencies.

In total 26 bedload traps were lost at the 18 research plots during the first field season. Thus, on average, at every sampling spot the traps were lost 1.5 times. Hence, we found that a major disadvantage of the bedload samplers is their big contact surface, making them more susceptible to scouring at high discharge. For those reasons, no bedload traps were installed during the second field season.

\subsection{Comparison of the different methods}

\subsubsection{SS samplers and OBS turbidity sensors}

Results clearly suggest that both the SS samplers and the OBS turbidity sensors are suitable to capture large scale spatial and temporal variations in suspended sediment concentrations or loads (Table 2). The two methods revealed a significant increase in suspended sediment (both SS load and SS concentration) along the river and significantly higher sus- pended sediment in the 2009/1010 season than the 2010/2011 season. Similarly, both methods showed a significantly positive Spearman correlation between SS and water level (Table 8). The weak correlation between SSC $_{\mathrm{NTU}}$ and water level at site B was probably related to measurement problems with the OBS sensor due to leaves caught by the sensor (see Sect. 3.1.1). Even though the methods differ in their quantitative results, correlation analysis showed a significant correlation between SS load caught by the sampler during one week and the average $\mathrm{SSC}_{\mathrm{NTU}}$ that week (Table 8).

The advantage of the SS samplers is their relatively low cost and their easy mounting, making a high spatial distribution across the channel possible. Therefore, the correlation between SS loads obtained with the SS samplers and the sediment infiltration rate was better than the correlation between SSC $_{\text {NTU }}$ assessed by OBS sensors and the sediment infiltration rates (Table 8). SS sampler data are positively correlated to fine sediment infiltration (Table 8, Fig. 8). At a deposition of about $40 \mathrm{~kg} \mathrm{~m}^{-2}$, saturation or equilibrium of input and scouring was reached at site B and C. At site A, deposition increased until about $60 \mathrm{~kg} \mathrm{~m}^{-2}$. This can be explained by less scouring at site A attributable to lower water levels. OBS data are only weakly correlated with sediment infiltration (Table 8) probably due to the cross channel differences in SS or measurement biases discussed earlier. Cross channel differences cannot be assessed with only one point measurement of $\mathrm{SSC}_{\mathrm{NTU}}$ per site. Certainly, a higher cross channel resolution could also be obtained by mounting multiple OBS sensors across the channel. But the installation of the sensors across the channel could be quite difficult and would also be connected with high costs.

\subsubsection{Sediment infiltration baskets and bedload traps}

Fine sediment infiltration rates measured with the sediment baskets correlated significantly with sediment transported as bedload measured with the bedload traps (Table 8). A nonlinear regression (saturation curve) describes the observed relationship best (Fig. 9, left). Values above a sediment infiltration rate of $2 \mathrm{~kg} \mathrm{~m}^{-2} \mathrm{~d}^{-1}$ are highly variable, probably attributable to higher scouring. While sediment infiltration baskets reach a saturation around $10 \mathrm{~kg} \mathrm{~m}^{-2} \mathrm{~d}^{-1}$, bedload traps can capture sediments until about $15 \mathrm{~kg} \mathrm{~m}^{-2} \mathrm{~d}^{-1}$ because of their large volume (Fig. 9, left). Consequently, 
Table 8. Spearman rank correlation coefficients $(\rho)$ between the measured parameters of both seasons for the three sites with mean weekly SSC $_{\text {NTU }}$ measured with OBS sensors, total weekly suspended sediment (SS) load measured by SS samplers, daily fine sediment infiltration rate, fine sediment accumulation, daily bedload of fine sediment, the percentage of fine sediment of the total bedload, highest mean daily water level of a week and vertical hydraulic gradient (VHG). The accumulation baskets were correlated with the mean values of the parameters during the whole field seasons. The sample size $(n)$ is given in parentheses.

\begin{tabular}{|c|c|c|c|c|c|c|c|}
\hline & SS & Infiltration & Accu. & Bedload & Bedload (\%) & Water level & VHG \\
\hline $\begin{array}{l}\mathrm{SSC}_{\mathrm{NTU}} \\
\left(\mathrm{mg} 1^{-1}\right)\end{array}$ & $\begin{array}{r}0.8(212)^{* *} \\
0.2(204)^{*} \\
0.7(204)^{* *}\end{array}$ & $\begin{array}{l}0.8(218)^{* *} \\
0.2(204)^{* *} \\
0.5(204)^{* *}\end{array}$ & $\begin{array}{r}0.8(14)^{* *} \\
0.2(6) \\
0.6(6)\end{array}$ & $\begin{array}{c}0.7(104)^{* *} \\
-0.4(96)^{*} \\
0.8(90)^{* *}\end{array}$ & $\begin{array}{r}-0.4(104)^{* *} \\
0.1(96) \\
-0.5(90)^{* *}\end{array}$ & $\begin{array}{l}0.7(196)^{* *} \\
0.2(204)^{* *} \\
0.9(180)^{* *}\end{array}$ & $\begin{array}{r}0.2(131)^{*} \\
0.1(121) \\
0.2(90)\end{array}$ \\
\hline $\begin{array}{l}\text { SS } \\
\left(\mathrm{g} \mathrm{week}^{-1}\right)\end{array}$ & & $\begin{array}{l}0.9(212)^{* *} \\
0.9(204)^{* *} \\
0.8(204)^{* *}\end{array}$ & $\begin{array}{r}0.8(14)^{* *} \\
-0.4(6) \\
0.8(6)\end{array}$ & $\begin{array}{c}0.8(104)^{* *} \\
0.8(96)^{* *} \\
0.8(90)^{* *}\end{array}$ & $\begin{array}{r}-0.4(104)^{* *} \\
-0.4(96)^{* *} \\
-0.5(90)^{* *}\end{array}$ & $\begin{array}{l}0.6(212)^{* *} \\
0.8(204)^{* *} \\
0.8(204)^{* *}\end{array}$ & $\begin{array}{r}0.3(131)^{* *} \\
0.4(121)^{* *} \\
0.2(90)\end{array}$ \\
\hline $\begin{array}{l}\text { Infiltration } \\
\left(\mathrm{kg} \mathrm{m}^{2} \mathrm{~d}^{-1}\right)\end{array}$ & & & $\begin{array}{r}0.6(14)^{*} \\
0.0(6) \\
0.3(6)\end{array}$ & $\begin{array}{c}0.9(104)^{* *} \\
0.8(96)^{* *} \\
0.9(90)^{* *}\end{array}$ & $\begin{array}{c}-0.4(104)^{* *} \\
-0.5(96)^{* *} \\
-0.6(90)^{* *}\end{array}$ & $\begin{array}{l}0.7(218)^{* *} \\
0.8(204)^{* *} \\
0.6(204)^{* *}\end{array}$ & $\begin{array}{r}0.3(131)^{* * *} \\
0.4(121)^{* *} \\
0.0(90)\end{array}$ \\
\hline $\begin{array}{l}\text { Accu. } \\
(\%<2 \mathrm{~mm})\end{array}$ & & & & $\begin{array}{l}-(4) \\
-(2) \\
-(2)\end{array}$ & $\begin{array}{l}-(4) \\
-(2) \\
-(2)\end{array}$ & $\begin{array}{r}-0.6(14)^{*} \\
0.1(6) \\
-0.2(6)\end{array}$ & $\begin{array}{r}-0.3(14) \\
-0.6(6) \\
-0.1(6)\end{array}$ \\
\hline $\begin{array}{l}\text { Bedload } \\
\left(\mathrm{kg} \mathrm{m}^{2} \mathrm{~d}^{-1}\right)\end{array}$ & & & & & $\begin{array}{r}-0.4(104)^{* *} \\
-0.4(96)^{* *} \\
-0.6(90)^{* *}\end{array}$ & $\begin{array}{c}0.9(104)^{* *} \\
0.7(96) * * \\
0.8(90)^{* *}\end{array}$ & $\begin{array}{l}0.2(57) \\
0.2(39) \\
0.0(35)\end{array}$ \\
\hline $\begin{array}{l}\text { Bedload } \\
(\%<2 \mathrm{~mm})\end{array}$ & & & & & & $\begin{array}{r}-0.5(104)^{* *} \\
-0.2(96)^{*} \\
-0.6(90)^{* *}\end{array}$ & $\begin{array}{r}0.1(57) \\
0.1(39) \\
-0.2(35)\end{array}$ \\
\hline $\begin{array}{l}\text { Water level } \\
(\mathrm{cm})\end{array}$ & & & & & & & $\begin{array}{r}0.1(131) \\
0.4(121)^{* *} \\
0.2(90)\end{array}$ \\
\hline
\end{tabular}

$* p<0.05 . * * p<0.01$.

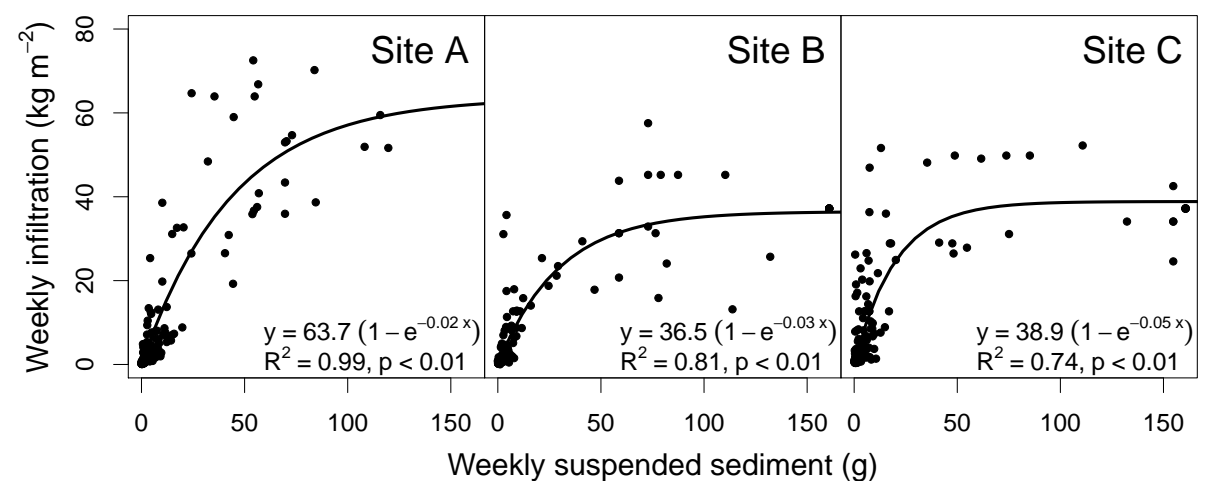

Fig. 8. Weekly sediment infiltration in relation to the total weekly SS load assessed with SS samplers at the three sites. $R^{2}$ and $p$ of the nonlinear regressions were calculated after Zuur et al. (2009).

sediment infiltration baskets are filled very quickly at high water level if not emptied in short enough intervals.

Results suggest a linear relationship of the data with smaller sediment infiltration rates $\left(0\right.$ to $2 \mathrm{~kg} \mathrm{~m}^{-2} \mathrm{~d}^{-1}$; Fig. 9 , right). According to Bond (2002), sediment infiltration is governed primarily by sediment supply or transport rates un- til the point when interstitial spaces become clogged with fine sediments. The data from this study support this statement qualitatively (see Sect. 3.2 and the highly significant correlation between both water level and SS load with sediment infiltration rates as well as with bedload rates, Table 8 ). The sediment infiltration rates are, however, almost 

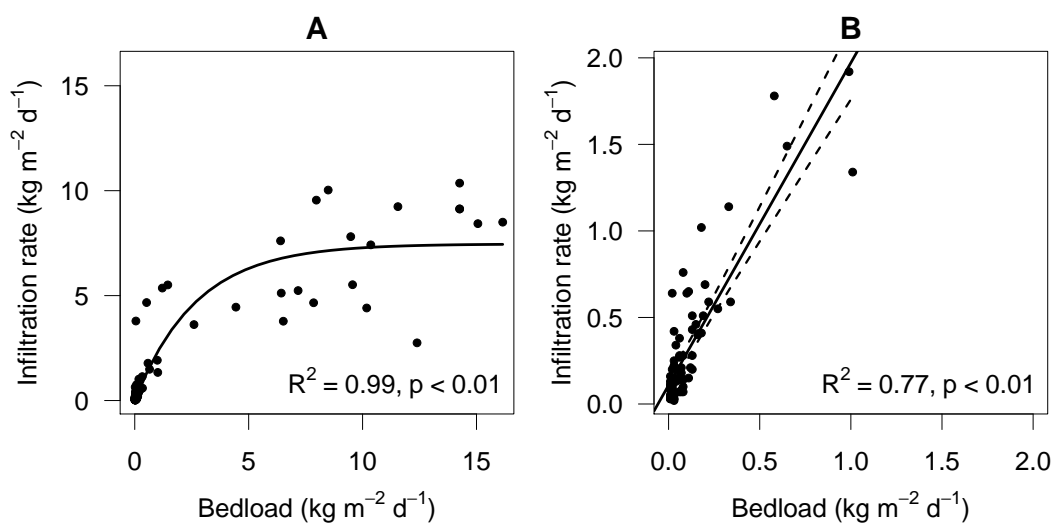

Fig. 9. Relationship between infiltration rate of fine sediment measured with sediment baskets and bedload measured with bedload traps at site A. (A): all data with a nonlinear regression line, $R^{2}$ and $p$ were calculated after Zuur et al. (2009); (B): linear regression for data with infiltration rates smaller $2 \mathrm{~kg} \mathrm{~m}^{-2} \mathrm{~d}^{-1}$, dashed lines are the $95 \%$ confidence intervals.

twice the bedload until the mentioned level at a sediment infiltration rate of $2 \mathrm{~kg} \mathrm{~m}^{-2} \mathrm{~d}^{-1}$ (Fig. 9, right). This is probably attributable to an instrumental bias of the bedload samplers. According to Bond (2002), trapping efficiency of the bedload traps is lower for the silt and fine sand $(<0.25 \mathrm{~mm})$ fractions (only $20-40 \%$ at some sites). During low sediment infiltration rates, this fraction accounted for most of the infiltrated sediments (Fig. 7). In contrasts to the sediment infiltration baskets, where infiltrated sediments are caught in a matrix of coarse sediment, fines can be easier washed out of bedload traps. A closer assessment of the differences in trapping efficiency of the sediment infiltration baskets and the bedload traps can only be accomplished under well defined conditions in a stream channel.

Sediment caught by bedload traps is mainly dependent on the water level and SS load. Because of the solid wall of the traps, the vertical hydraulic gradient has no influence on this process (Table 8 ). In contrast, less fine sediment infiltration was expected with a positive vertical hydraulic gradient (= upwelling) in the sediment infiltration baskets. This has been shown in previous studies (Brunke, 1999; Seydell et al., 2009). This relationship, however, was not observed in this study: at sites A and B, fine sediment infiltration was slightly higher in upwelling zones compared to downwelling zones (Table 8). This is likely attributable to the high variability of hydrological exchange processes (e.g. Brunke and Gonser, 1997). The vertical hydraulic gradient measurements represent only the specific hydraulic conditions at a certain time while sediment infiltration was measured over a week with possible changing vertical hydraulic gradients.

Multiple regression analyses for sediment infiltration as response variable with SS load (measured by SS sampler), $\mathrm{SSC}_{\mathrm{NTU}}$, bedload, water level and vertical hydraulic gradient as explanatory variables were conducted. SS load as single explanatory variable was the best predictor for sediment infiltration at all sites. Due to the equilibration or saturation of sediment infiltration, the sediment infiltration rate is best described by a nonlinear regression model (Fig. 8). As such, the strong correlation between sediment infiltration and the occurrence of fine sediment in the water column found in other studies (Acornley and Sear, 1999; Zimmermann and Lapointe, 2005) could be confirmed.

\subsubsection{Sediment accumulation baskets}

Only a small number of accumulation baskets resisted the flood; consequently, only a small data set across the two field seasons was available (site A: $n=14$, site B: $n=6$, site $\mathrm{C}: n=6$ ). This makes statistical analyses difficult and only general conclusions concerning the net fine sediment accumulation are possible (see Sect. 3.3). Fine sediment accumulation decreased from upstream to downstream, i.e., from site A to site C. In contrast, SS concentration and load and bedload increased from upstream to downstream, while fine sediment infiltration did not differ significantly between the sites. This is probably attributable to the higher resuspension and scouring of fines downstream due to higher water level, resulting in higher SS concentration and bedload, but smaller net sediment infiltration and accumulation.

Spearman rank analyses between sediment accumulation and other methods are only feasible at site A, which has the largest dataset. These analyses indicate a positive correlation between accumulated fine sediment and mean SS load $(\rho=$ $0.8, p<0.01)$ as well as mean infiltration of fines $(\rho=0.6$, $p<0.05$; Table 8).

Higher mean water levels above the accumulation baskets lead to resuspension of fine sediment, resulting in a negative Spearman rank correlation between water level and sediment accumulation $(\rho=-0.6, p<0.05$; Table 8$)$. A smaller amount of fine sediment accumulation in plots with higher water level and flow velocity compared to plots with lower water level was reported previously (e.g. Acornley and Sear, 1999; Levasseur et al., 2006). Finally, multiple linear 
regression analyses with SS load and vertical hydraulic gradient (VHG) as explanatory variables indicate less sediment accumulation in upwelling zones than in downwelling zones:

$$
\begin{aligned}
\text { Accumulation } & =14.2+0.6 \times \mathrm{SS}-21.5 \times \mathrm{VHG}, \\
R^{2} & =0.7, p<0.05
\end{aligned}
$$

The results of Seydell et al. (2009) support these findings. They even noted that subsurface flow patterns have a larger influence on sediment deposition than the suspended sediment concentration in the river. Due to cross correlations between the mentioned dependent variables (Table 8), other multiple regressions are not possible.

\section{Conclusions}

We compared different methods to capture temporal and spatial dynamics of suspended sediment (SS), fine sediment infiltration and accumulation. These methods were correlated and tested for their suitability for a river in the Swiss Plateau. A comparison to other studies as well as a cross-comparison between methods indicated a general agreement between the methods. All methods are, however, connected with some instrumental and sampling errors, which can not always be distinguished from spatial heterogeneity in the river. This calls for laboratory tests to assess the instrumental biases under controlled hydraulic and sediment conditions.

Methods to capture SS (OBS sensors and SS samplers) indicate big spatial and temporal differences in SS. OBS data have a higher temporal resolution. SS samplers can provide important information on the composition of SS and a better spatial distribution can be achieved because of their relatively low construction cost. Due to the dense sampling network the correlation between SS load collected with SS samplers and sediment infiltration rate was better than between sediment infiltration rate and $\mathrm{SSC}_{\mathrm{NTU}}$ assessed by a single $\mathrm{OBS}$ sensor per site.

Sediment infiltration baskets are a quasi standardized method to obtain spatial and temporal differences of fine sediment infiltration but do not represent natural conditions. Sediment $<4 \mathrm{~mm}$ are removed at regular intervals, causing an overestimation of the real capacity of sediment infiltration in an undisturbed riverbed. Sediment infiltration is mainly governed by water level and SS concentration. A major hydrological event can result in a total siltation of the sediment infiltration baskets. With higher water levels, scouring increases, resulting in a equilibrium between SS input and scouring. Bedload traps have a larger volume than sediment infiltration baskets, but they are associated with other problems as the difficulty to dig them flush into the riverbed. Furthermore, they are susceptible to scouring at high flows due to their large contact surface. We conclude that sediment infiltration baskets are better suited for a highly dynamic canalized river of the Swiss Plateau.
Sediment accumulation baskets do not assess the temporal behaviour of fine sediment infiltration but the accumulation over a certain time period. The loss of baskets at high flow generated the biggest problem associated with the accumulation baskets. They can not be renewed as their purpose is the assessment of accumulation during the entire field period. Additionally, they overestimate the fine sediment proportion. Differences in the effective size of the pore spaces, the gap between the inner and the outer sediment baskets or the solid bottom of the baskets are possible reasons for this overestimation. Less fine sediment accumulates in upwelling zones and with a higher mean water level due to scouring. Even though SS concentration and load and sediment assessed with the bedload traps increased from upto downstream, less fine sediment accumulated downstream. This was probably due to more scouring downstream.

Acknowledgements. This study was funded by the Swiss national foundation (SNF K-32K1-32K1-120486). We would like to thank Nicolas Gratiot and the RIVER team, Dirk de Boer, an anonymous reviewer and the editor Ilja van Meerveld for the constructive comments. They were a great help to improve the manuscript. We thank Annina Gysel, Sandra Rudolf and Bastian Brun for their help in the field, Philipp Amrein and Sepp Lustenberger for support during the field work, Marianne Caroni and Ruth Strunk for laboratory assistance and Claude Schneider for technical support.

Edited by: I. van Meerveld

\section{References}

Acornley, R. M. and Sear, D. A.: Sediment transport and siltation of brown trout (Salmo trutta L.) spawning gravels in chalk streams, Hydrol. Process., 13, 447-458, 1999.

Asselman, N. E. M., Middelkoop, H., and van Dijk, P. M.: The impact of changes in climate and land use on soil erosion, transport and deposition of suspended sediment in the River Rhine, Hydrol. Process., 17, 3225-3244, doi:10.1002/hyp.1384, 2003.

Baxter, C., Hauer, F. R., and Woessner, W. W.: Measuring groundwater-stream water exchange: New techniques for installing minipiezometers and estimating hydraulic conductivity, T. Am. Fish. Soc., 132, 493-502, 2003.

Bilotta, G. S. and Brazier, R. E.: Understanding the influence of suspended solids on water quality and aquatic biota, Water Res., 42, 2849-2861, doi:10.1016/j.watres.2008.03.018, 2008.

Bond, N. R.: A simple device for estimating rates of fine sediment transport along the bed of shallow streams, Hydrobiologia, 468, 155-161, 2002.

Brunke, M.: Colmation and depth filtration within streambeds: Retention of particles in hyporheic interstices, Int. Rev. Hydrobiol., 84, 99-117, 1999.

Brunke, M. and Gonser, T.: The ecological significance of exchange processes between rivers and groundwater, Freshw. Biol., 37, 133, 1997.

Bucher, R.: Feinsedimente in schweizerischen Fliessgewässern, Fischnetz-Publikation. Projekt "Netzwerk Fischrückgang Schweiz”, Teilprojekt 01/07, EAWAG, Dübendorf, 2002. 
Downing, J.: Twenty-five years with OBS sensors: The good, the bad, and the ugly, Cont. Shelf Res., 26, 2299-2318, doi:10.1016/j.csr.2006.07.018, 2006.

Duvert, C., Gratiot, N., Evrard, O., Navratil, O., Nemery, J., and Prat, C. and Esteves, M.: Drivers of erosion and suspended sediment transport in three headwater catchments of the Mexican Central Highlands, Geomorphology, 123, 243-256, doi:10.1016/j.geomorph.2010.07.016, 2010.

EBP-WSB-Agrofutura: Ganzheitliche Gewässerplanung im Einzugsgebiet Wiggertal, Bau- und Umwelt und Wirtschaftsdepartement des Kantons Luzern und Baudepartement des Kantons Aargau, 2005.

Fehr, R.: Einfache Bestimmung der Korngrössenverteilung von Geschiebematerial mit Hilfe der Linienzahlanalyse, Schweizer Ingenieur und Architekt, 38, 1104-1109, 1987.

Greig, S. M., Sear, D. A., and Carling, P. A.: The impact of fine sediment accumulation on the survival of incubating salmon progeny: Implications for sediment management, Sci. Total Environ., 344, 241-258, doi:10.1016/j.scitotenv.2005.02.010, 2005.

Heywood, M. J. T. and Walling, D. E.: The sedimentation of salmonid spawning gravels in the Hampshire Avon catchment, UK: implications for the dissolved oxygen content of intragravel water and embryo survival, Hydrol. Process., 21, 770-788, doi:10.1002/hyp.6266, 2007.

Horowitz, A. J., Rinella, F. A., Lamothe, P., Miller, T. L., Edwards, T. K., Roche, R. L., and Rickert, D. A.: Variations in suspended sediment and associated trace-element concentrations in selected riverine cross-sections, Environ. Sci. Technol., 24, 1313-1320, doi:10.1021/es00079a003, 1990.

Hütte, M. and Niederhauser, P.: Ökomorphologie Stufe F. Methoden zur Untersuchung und Beurteilung der Fliessgwässer in der Schweiz, Bundesamt für Umwelt, Wald und Landschaft, Mitteilungen zum Gewässerschutz, 27, 1998.

IUSS: World reference base for soil resources, Tech. Rep., FAO, 2006.

Julien, H. and Bergeron, N.: Effect of fine sediment infiltration during the incubation period on Atlantic salmon (Salmo salar) embryo survival, Hydrobiologia, 563, 61-71, 2006.

Levasseur, M., Bergeron, N., Lapointe, M., and Bérubé, F.: Effects of silt and very fine sand dynamics in Atlantic salmon (Salmo salar) redds on embryo hatching success, Can. J. Fish. Aquat. Sci., 63, 1450-1459, 2006.

Lisle, T. E.: Sediment transport and resulting deposition in spawning gravels, North Coastal California, Water Resour. Res., 25, 1303-1319, 1989.

Lisle, T. E. and Lewis, J.: Effects of sediment transport on survival of salmonid embryos in a natural stream - a simulation approach, Can. J. Fish. Aquat. Sci., 49, 2337-2344, 1992.

Minella, J. P. G., Merten, G. H., Reichert, J. M., and Clarke, R. T.: Estimating suspended sediment concentrations from turbidity measurements and the calibration problem, Hydrol. Process., 22, 1819-1830, doi:10.1002/hyp.6763, 2008.

Navratil, O., Esteves, M., Legout, C., Gratiot, N., Nemery, J., Willmore, S., and Grangeon, T.: Global uncertainty analysis of suspended sediment monitoring using turbidimeter in a small mountainous river catchment, J. Hydrol., 398, 246-259, doi:10.1016/j.jhydrol.2010.12.025, 2011.

Newcombe, C. and Jensen, J.: Channel suspended sediment and fisheries: A synthesis for quantitative assessment of risk and im- pact, N. Am. J. Fish. Manage., 16, 693-727, 1996.

Owens, P., Batalla, R., Collins, A., Gomez, B., Hicks, D., Horowitz, A., Kondolf, G., Marden, M., Page, M., Peacock, D., Petticrew, E., Salomons, W., and Trustrum, N.: Fine-grained sediment in river systems: Environmental significance and management issues, River Res. Appl., 21, 693-717, 2005.

Packman, J., Comings, K., and Booth, D.: Using turbidity to determine total suspended solids in urbanizing streams in the puget lowlands, in: Managing change in water resources and the environment, Can. Wat. Resour. Association Annual Meeting, 158165, Vancouver, 1999.

Phillips, J. M., Russell, M. A., and Walling, D. E.: Time-integrated sampling of fluvial suspended sediment: a simple methodology for small catchments, Hydrol. Process., 14, 2589-2602, 2000.

Schälchli, U.: Basic equations for siltation of riverbeds, J. Hydraul. Eng.-Asce, 121, 274-287, 1995.

Scheurer, K., Alewell, C., Bänninger, D., and Burkhardt-Holm, P.: Climate and land-use changes affecting river sediment and brown trout in alpine countries - a review, Environ. Sci. Pollut. R., 16, 232-242, doi:10.1007/s11356-008-0075-3, 2009.

Sear, D. A.: Fine sediment infiltration into gravel spawning beds within a regulated river experiencing floods - ecological implications for salmonids, Regul. Rivers-Res. Manage., 8, 373-390, 1993.

Sear, D. A., Frostick, L., Rollinson, G., and Lisle, T.: The significance and mechanics of fine-sediment infiltration and accumulation in gravel spawning beds, Am. Fish. Soc. Symposium, 65, 149-173, 2008.

Seydell, I., Ibisch, R., and Zanke, U.: Intrusion of suspended sediments into gravel riverbeds: influence of bed topography studied by means of field and laboratory experiments, Advanc. Limnol., 61, 67-85, 2009.

Soulsby, C., Youngson, A., Moir, H., and Malcolm, I.: Fine sediment influence on salmonid spawning habitat in a lowland agricultural stream: a preliminary assessment, Sci. Total Environ., 265, 295-307, 2001.

Sponagel, H., Grottenthaler, W., Hartmann, K.-J., Hartwich, R., Janetzko, P., Joisten, H., Kuhn, D., Sabel, K.-J., and Traidl, R.: Bodenkundliche Kartieranleitung, Bundesanstalt für Geowissenschaften und Rohstoffe, Hannover, 2005.

Spreafico, M., Lehmann, C., Jakob, A., and Grasso, A.: Feststoffbeobachtung in der Schweiz, Tech. Rep., Bundesamt für Wasser und Geologie/Swiss Federal Office for Water and Geology, 2005.

Stucki, P.: Methoden zur Untersuchung und Beurteilung der Fliessgewässer. Makrozoobenthos Stufe F, Bundesamt für Umwelt, Bern, Umwelt-Vollzug, 1027, 2010.

Young, M., Hubert, W., and Wesche, T.: Biases associated with four stream substrate samplers, Can. J. Fish. Aquat. Sci., 48, 1882$1886,1991$.

Zimmermann, A. E. and Lapointe, M.: Sediments infiltraion traps: their use to monitor salmonid spawning habitat in headwater tributaries of the Cascapedia River, Quebec, Hydrol. Process., 19, 4161-4177, doi:10.1002/hyp.5879, 2005.

Zimmermann, A., Coulombe-Pontbriand, M., and Lapointe, M.: Biases of submerged bulk and freeze-core samples, Earth Surf. Proc. Land., 30, 1405-1417, doi:10.1002/esp.1202, 2005.

Zuur, F. A., Ieno, E. N., Walker, N. J., Saveliev, A. A., and Smith, G. M.: Mixed effects models and extensions in ecology with R, Springr Science + Business Media, New York, 2009. 